\title{
A STRUCTURED APPROACH TO CALCULATING REASONABLE ROYALTIES ${ }^{\dagger}$
}

\author{
Daralyn J. Durie ${ }^{*}$ and Mark A. Lemley ${ }^{* *}$
}

A significant part of the problem with patent damage awards comes from the non-exclusive, fifteen-factor "Georgia-Pacific" test now taken as the gold standard for calculating reasonable royalty damages. Simply handing the question of reasonable royalty to the jury, without more, is not a recipe for precision in damages analysis. But the fifteen-factor test may actually be worse, because it overloads the jury with factors to consider that may be irrelevant, overlapping, or even contradictory. And because the jury's finding is the result of such a complex, multi-factor test, it is, as a practical matter, almost entirely immune from scrutiny by either district or appellate judges facing a deferential standard of review.

The Authors suggest a structured approach to calculating reasonable royalties. Most of the factors in the Georgia-Pacific test in fact boil down to three fundamental questions: (1) what is the marginal contribution of the patented invention over the prior art?; (2) how many other inputs were necessary to achieve that contribution, and what is their relative value?; and (3) is there some concrete evidence suggesting that the market has chosen a number different than the product of (1) and (2)? By structuring the inquiry in this way, courts (or Congress) can not only simplify the question for the jury, but also enable district courts and the Federal Circuit to easily review the factual basis for a jury award.

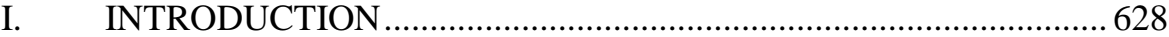

II. ARE FIFTEEN FACTORS BETTER THAN NONE? .........................629

III. DO JUDGES DEFER TO JURY VERDICTS AWARDING

REASONABLE ROYALTIES?

IV. STRUCTURING THE REASONABLE ROYALTY INQUIRY ........636

A. Organizing and Simplifying the Georgia-Pacific Factors.............636

1. Nature of the Patentee ................................................................ 636

2. The Incremental Contribution of the Patented Technology ... 637

3. Other Inputs to the Patented Invention .................................... 639

† (C) 2010 Daralyn J. Durie \& Mark A. Lemley.

* Partner, Durie Tangri LLP, San Francisco, California.

** William H. Neukom Professor, Stanford Law School; partner, Durie Tangri LLP, San Francisco, California. Thanks to Rose Hagan and Stephen Johnson for comments on an earlier draft. 


\section{INTRODUCTION}

The calculation of patent damages has become one of the most contentious issues in all of intellectual property (IP) law. The popular press reports enormous damage awards for patent infringement, ranging sometimes into the billions of dollars. ${ }^{1}$ Scholars debate whether the damage rules result in systematic overcompensation of patentees. ${ }^{2}$ Damages reform has been not only the centerpiece of Congressional efforts to reform the patent statute over the last five years, but the piece that has caused the entire process to grind to a halt, as various constituencies are unable to come to agreement on how to fix the damage rules. ${ }^{3}$

In this Article we argue that a significant part of the problem comes from the non-exclusive, fifteen-factor "Georgia-Pacific" test ${ }^{4}$ now taken as the gold standard for calculating reasonable royalty damages. Simply handing the question of reasonable royalty to the jury, without more, is not a recipe for precision in damages analysis. But the fifteen-factor test may actually be worse because it overloads the jury with factors to consider that may be irrelevant, overlapping, or even contradictory. And because the jury's finding is the result of such a complex, multi-factor test, it is as a practical matter almost entirely immune from scrutiny by either district or appellate judges facing a deferential standard of review. With fifteen factors, lawyers can make an argument that some combination of factors will support virtually any number an expert (or a jury) might come up with. As long as juries have virtual carte blanche to pick a

1 See, e.g., Microsoft Hit With \$1.52 Billion Patent Damage Verdict, http://www.reuters.com/article/idUSWEN465120070223 (reporting original jury verdict in Lucent Techs., Inc. v. Gateway, Inc., 580 F. Supp. 2d 1016, 1028 (S.D. Cal. 2008), rev'd 580 F.3d 1301, 1308 (Fed. Cir. 2009)); Centocor Ortho Biotech, Inc. v. Abbott Labs., 2:07-CV139-TJW, 2009 WL 3734119 (E.D. Tex. Nov. 4, 2009) (\$1.67 billion award, before enhancement).

2 See, e.g., Thomas F. Cotter, Patent Holdup, Patent Remedies, and Antitrust Responses, 34 J. CORP. L. 1151, 1152-53 (2009); Einer Elhauge, Do Patent Holdup and Royalty Stacking Lead to Systematically Excessive Royalties?, 4 J. COMPETITION L. \& ECON. 535, 535-36 (2008); John Golden, "Patent Trolls” and Patent Remedies, 85 Tex. L. Rev. 2111, 2112 (2007); Mark A. Lemley \& Carl Shapiro, Patent Holdup and Royalty Stacking, 85 TEX. L. REV. 1991, 1994 (2007); J. Gregory Sidak, Holdup, Royalty Stacking, and the Presumption of Injunctive Relief for Patent Infringement: A Reply to Lemley \& Shapiro, 92 MinN. L. REV. 714, 714 (2008).

3 See, e.g., Dan L. Burk \& Mark A. Lemley, The Patent Crisis and How the COURTS CAN SOLVE IT 4 (2009).

${ }^{4}$ Georgia-Pac. Corp. v. U.S. Plywood Corp., 318 F. Supp. 1116, 1120 (S.D.N.Y. 1970), modified sub nom. Georgia-Pac. Corp. v. U.S. Plywood-Champion Papers Inc., 446 F.2d 295 (2d Cir. 1971). 
damages number, plaintiffs will continue to have an incentive to shoot for the moon, and the problems of excessive damages will continue.

We suggest a structured approach to calculating reasonable royalties. Most of the factors in the Georgia-Pacific test, in fact, boil down to three fundamental questions: (1) what is the marginal contribution of the patented invention over the prior art?; (2) how many other inputs were necessary to achieve that contribution, and what is their relative value?; and (3) is there some concrete evidence suggesting that the market has chosen a number different than the calculus that results from (1) and (2)? By structuring the inquiry in this way, courts (or Congress) will not only simplify the question for the jury, but also enable district courts and the Federal Circuit to easily review the factual basis for a jury award.

In Part II, we discuss the Georgia-Pacific test and its failings. Part III investigates the ability of district and appellate courts to review reasonable royalty findings. Part IV discusses our proposed alternative, which uses the same substantive questions as the Georgia-Pacific test, but considers them in a more helpful way.

\section{ARE FIFTEEN FACTORS BETTER THAN NONE?}

The universally accepted test for reasonable royalty damages comes, perhaps improbably, from a 1970 district court case ${ }^{5}$ that itself adopted verbatim the incomplete draft opinion of a deceased judge ${ }^{6}$ and that was modified in significant part by the Second Circuit on appeal. ${ }^{7}$ That opinion noted that "[a] comprehensive list of evidentiary facts relevant, in general, to the determination of the amount of a reasonable royalty for a patent license may be drawn from a conspectus of the leading cases." ${ }^{8}$

However, the court did not actually set out that comprehensive list of evidentiary facts. Instead, it listed only the ones that seemed to apply to the case before it:

The following are some of the factors mutatis mutandis seemingly more pertinent to the issue herein:

1. The royalties received by the patentee for the licensing of the patent in suit, proving or tending to prove an established royalty.

2. The rates paid by the licensee for the use of other patents comparable to the patent in suit.

3. The nature and scope of the license, as exclusive or non-exclusive; or as restricted or non-restricted in terms of territory or with respect to whom the manufactured product may be sold.

4. The licensor's established policy and marketing program to maintain his patent monopoly by not licensing others to use the invention or by

5 Id. at 1116.

6 Id. at 1119 n.3.

7 Georgia-Pac. Corp., 446 F.2d at 296.

8 Georgia-Pac. Corp., 318 F. Supp. at 1120. 
granting licenses under special conditions designed to preserve that monopoly.

5. The commercial relationship between the licensor and licensee, such as, whether they are competitors in the same territory in the same line of business; or whether they are inventor and promotor.

6. The effect of selling the patented specialty in promoting sales of other products of the licensee; the existing value of the invention to the licensor as a generator of sales of his non-patented items; and the extent of such derivative or convoyed sales.

7. The duration of the patent and the term of the license.

8. The established profitability of the product made under the patent; its commercial success; and its current popularity.

9. The utility and advantages of the patent property over the old modes or devices, if any, that had been used for working out similar results.

10. The nature of the patented invention; the character of the commercial embodiment of it as owned and produced by the licensor; and the benefits to those who have used the invention.

11. The extent to which the infringer has made use of the invention; and any evidence probative of the value of that use.

12. The portion of the profit or of the selling price that may be customary in the particular business or in comparable businesses to allow for the use of the invention or analogous inventions.

13. The portion of the realizable profit that should be credited to the invention as distinguished from non-patented elements, the manufacturing process, business risks, or significant features or improvements added by the infringer.

14. The opinion testimony of qualified experts.

15. The amount that a licensor (such as the patentee) and a licensee (such as the infringer) would have agreed upon (at the time the infringement began) if both had been reasonably and voluntarily trying to reach an agreement; that is, the amount which a prudent licensee-who desired, as a business proposition, to obtain a license to manufacture and sell a particular article embodying the patented invention-would have been willing to pay as a royalty and yet be able to make a reasonable profit and which amount would have been acceptable by a prudent patentee who was willing to grant a license. ${ }^{9}$

The factors the Georgia-Pacific court identified, then, were nonexclusive; these were simply the factors that were relevant to the case before it. In evaluating those factors the Georgia-Pacific court eschewed hard-and-fast rules like adding up the factors for each side, choosing instead a gestalt reading of the factors as a whole:

In the present case there is a multiplicity of inter-penetrating factors bearing upon the amount of a reasonable royalty. But there is no formula by which these factors can be rated precisely in the order of their relative 
importance or by which their economic significance can be automatically transduced into their pecuniary equivalent. ${ }^{10}$

Notably, when the Second Circuit reviewed the case it accepted the general evidentiary framework the district court had used, but it reduced the court's award substantially because the fifteen-factor test did not give adequate attention to the need for the defendant in a willing buyer-willing seller negotiation to make some residual profit. ${ }^{11}$

Nonetheless, it is the district court's opinion that has become gospel in the patent damages world. The Federal Circuit has cited the district court opinion in Georgia-Pacific thirty-two times. ${ }^{12}$ One of the two national patent jury instruction projects, the Federal Circuit Bar Association National Patent Jury Instructions, provides a list of factors that closely tracks Georgia-Pacific, and expressly lists the fifteen factors in a footnote. ${ }^{13}$ And at least one of the many patent reform proposals being considered in Congress, offered by Senator Feinstein, takes as given the fifteen Georgia-Pacific factors. ${ }^{14}$

Unfortunately, a non-exclusive fifteen-factor test that requires balancing and consideration of the interactions between the factors is likely to give little or no practical guidance to a jury. Juries are good at finding facts. But weighing the legal significance of those facts once they are found is rightly the province of the courts. ${ }^{15}$ Juries are unlikely to know-and unlikely to hear evidence that helps them decide-whether and how to weigh the importance of "[t]he commercial relationship between the licensor and licensee, such as, whether they are competitors in the same territory in the same line of business; or whether they are inventor and promoter" (Georgia-Pacific factor number five) against "[t]he duration of the patent and the term of the license" (GeorgiaPacific factor number seven). ${ }^{16}$ The result is that juries regularly disregard the

10 Id. at $1120-21$.

11 Georgia-Pac. Corp., 446 F.2d at 296-97.

12 Westlaw search, CTAF database, “318 f.supp. 1116”, performed Aug. 17, 2009.

13 See Federal Circuit Bar Association Model Patent Jury Instructions (June 17, 2009), http://www.nationaljuryinstructions.org/documents/NationalPatentJuryInstr

uctions.pdf. The other, the Northern District of California Model Patent Jury Instructions, does not use the Georgia-Pacific factors but seeks to distill a "plain English" statement of the legal rules. Model Patent Jury Instructions for the Northern District of California 2 (Nov. 29, 2007), http://www.cand.uscourts.gov/cand/ ForAttys.nsf/d07d1927bb07c86c88256d6e005ce658/4ed41e5a5972b27a88256d6e005cee5d/ \$FILE/NDModel.nov07.pdf.

14 Senate Bill 515, as passed by the committee, does not explicitly codify the GeorgiaPacific factors, but requires the parties and the court to identify the factors and methodologies to be used in calculating damages. Patent Reform Act of 2009, S. 515, 111th Cong. § 284(b) (as reported by Senate, Apr. 2, 2009).

15 See, e.g., KSR Int'l Co. v. Teleflex Inc., 550 U.S. 398, 427 (2007). On the complex interaction between the fact-law distinction and the judge-jury role, see, e.g., Cybor Corp. v. FAS Techs., Inc., 138 F.3d 1448, 1454-56 (Fed. Cir. 1998) (en banc); Ronald J. Allen \& Michael S. Pardo, The Myth of the Law-Fact Distinction, 97 Nw. U. L. REV. 1769, 1781 (2003).

Georgia-Pac. Corp. v. U.S. Plywood Corp., 318 F. Supp. 1116, 1120 (S.D.N.Y. 1970). 
instructions, following their own (incorrect) instincts in deciding an appropriate measure of damages. ${ }^{17}$

The breadth of the available factors also means that it is difficult to exclude evidence or expert testimony espousing virtually any theory of reasonable royalty damages, no matter how outlandish. The multi-factor test makes it difficult for the court to exercise a gate-keeping function, because a wide range of evidence can be offered in support of one factor or another. And because it is exceedingly rare for all fifteen factors to point in the same direction, and Georgia-Pacific provides little guidance as to which factors must be accorded the most weight in any given case, the expert's ultimate conclusion, no matter how extreme, can usually be justified by at least some combination of them.

Finally, and most significantly, the fifteen-factor test makes it extremely difficult for judges to review a jury damage award for substantial evidence, either on judgment as a matter of law (JMOL) or on appeal. This wasn't much of a problem in 1970, when Georgia-Pacific was decided. That case, like 95\% of patent cases in that decade, was tried to a judge, not a jury. ${ }^{18}$ And judges must explain how they balance the factors. ${ }^{19}$ But by 1994, the situation had changed-70\% of patent trials were before a jury. ${ }^{20}$ The percentage of jury trials is likely even higher today. In our experience, the only cases that routinely go to bench trial are pharmaceutical cases involving generic drug manufacturers, in which there are no damages at issue and hence no constitutional right to a jury trial. So, as a practical matter, juries, not judges, are the ones tasked with evaluating patent damages in virtually every case.

Jury verdicts almost always award reasonable royalty damages as a simple number - either a percentage of sales or a dollar amount. A judge who must review that verdict for reasonableness faces a quandary. With at least fifteen factors, a complex interaction between them, and little limit on expert testimony on damages, there is likely to be evidence somewhere in the case that could be construed to support virtually any number the jury might settle on. So a court faced with reviewing a damage award may be inclined to simply give up and defer to whatever the jury awards. ${ }^{21}$ If, on the other hand, a court does try to exercise its substantive oversight authority, it will almost by definition be rebalancing the factors the jury putatively balanced. The choices-blind

17 See, e.g., Martha K. Gooding \& William C. Rooklidge, The Real Problem with Patent Infringement Damages, 91 J. PAT. \& TRADEMARK OfF. SOC’y 484, 485-89 (2009).

18 Herbert F. Schwartz, Patent Law \& Practice 129 (2d ed. 1995).

19 See Read Corp. v. Portec, Inc., 970 F.2d 816, 828 (Fed. Cir. 1992) (“To enable appellate review, a district court is obligated to explain the basis for the award . ...”).

20 SCHWARTZ, supra note 17 , at 130 .

21 There is legal support for rather substantial deference. The Federal Circuit has said that the jury's damage award "must be upheld unless the amount is 'grossly excessive or monstrous', clearly not supported by the evidence, or based only on speculation or guesswork.” Brooktree Corp. v. Advanced Micro Devices, Inc., 977 F.2d 1555, 1580 (Fed. Cir. 1992) (quoting L.A. Mem'l Coliseum Comm'n v. Nat'l Football League, 791 F.2d 1356, 1360 (9th Cir. 1986)). 
deference or substituting the judge's view of the evidence for the jury's-are not attractive. ${ }^{22}$

In the next Part, we explore empirically how judges have dealt with this quandary.

\section{DO JUDGES DEFER TO JURY VERDICTS AWARDING REASONABLE ROYALTIES?}

To investigate the effect of deference we looked at several different sources. We began by looking at all written Federal Circuit opinions dealing with reasonable royalties that cite or rely on Georgia-Pacific. There are surprisingly few. We found 31 such cases, and of those, 6 were not in fact opinions on the merits of the damages issue. ${ }^{23}$ Of the 25 cases on the merits, 17 opinions affirmed a jury's finding of reasonable royalty damages, and another reversed the district court's grant of JMOL. ${ }^{24}$ Seven rejected the verdict below on damages, remanding for a new trial or altering the damage award in some respect, though one of the reversals reversed a district court rather than a jury award. ${ }^{25}$ A $72 \%$ affirmance rate is not in itself that surprising. ${ }^{26}$ But keep in mind that these are just the published opinions. If we add in the Rule 36 affirmances, the affirmance rate creeps up to $77 \%{ }^{27}$

22 In Lucent Techs., Inc. v. Gateway, Inc., the Federal Circuit reversed a jury verdict awarding a lump sum royalty of $\$ 357,693,056.18$. 580 F.3d 1301, 1308 (Fed. Cir. 2009). Interestingly, the Federal Circuit distinguished in the opinion between two rubrics for determining a reasonable royalty, characterizing one approach of calculating the accused infringer's own projected profits and apportioning those profits between patent holder and infringer as an "analytical method," and distinguishing it from the "willing licensor-willing licensee" approach under Georgia-Pacific. Id. at 1324. But ultimately the court's holding rested on the undeveloped evidentiary record which, in the court's view, left essentially no support in the trial record for the jury's damage award. Id. at 1335. As to Georgia Pacific factor two, the rates paid by the licensee for the use of other patents, the court distinguished each of the license agreements upon which the plaintiff relied as being insufficiently similar to the hypothetical license to have been negotiated both in their terms and their subject matter (including, as to some, that they were for a running royalty, and the jury awarded a lump sum). Id. at 1326-32. As to factors ten and thirteen, the court concluded, unexceptionally, that the date picker feature in Outlook is a small part of a much larger software program and therefore offered little support for the award. Id. at 1332. As to factor eleven, the court again noted that the record was "conspicuously devoid" of evidence on the usage of the date picker feature. Id. at 1334. As to the remaining features, the court concluded that they balanced each other out, and thus could not, on balance, support the award. Id. at 1335. What is significant about the Lucent Techs., Inc. v. Gateway, Inc. decision, at least in part, is that it turned not on how the jury balanced competing considerations, or even how the Federal Circuit would do so, but instead that there were "substantial infirmities in the evidence" that mandated a reversal of the jury's award. Id.

23 See infra App. tbl.1.

${ }^{24}$ Id.

25 Id.

26 See, e.g., Kimberly A. Moore, Markman Eight Years Later: Is Claim Construction More Predictable?, 9 LEWIS \& ClARK L. REV. 231, 240-41 (2005).

27 See Lee Petherbridge \& R. Polk Wagner, The Federal Circuit and Patentability: An Empirical Assessment of the Law of Obviousness, 85 TEX. L. REV. 2051, 2077, 2079 n.139 (2007) (estimating that 20\% of Federal Circuit patent decisions are affirmed under Rule 36). 
The data on the use of JMOL are even more striking. The Stanford IP Litigation Clearinghouse collects data on every patent lawsuit filed in the United States since 2000. ${ }^{28}$ There are 267 cases that award patentees damages after a jury trial. ${ }^{29}$ In most, if not all of those cases, the defendant files a motion for JMOL.

Those motions are rarely granted, however, and even more rarely granted on the issue of damages. Courts in these 267 cases granted 27 JMOL motions. ${ }^{30}$ Of those 27, 7 reversed jury verdicts in favor of the accused infringer, finding for the patentee as a matter of law. ${ }^{31}$ We exclude them here, as none relate to damages. Of the remaining 20, 17 granted JMOL on the substantive merits of the patent case-validity, infringement, or unenforceability. ${ }^{32}$ Only 3 granted JMOL on the issue of damages, 2 vacating the damage award altogether and 1 granting remittitur. ${ }^{33}$ Thus, barely more than $1 \%$ of the damage awards were rejected or modified as a matter of law. Of those cases, 1 of the vacaturs was a lost profits case and 1 was a mixed lost-profits/reasonable royalty case. ${ }^{34}$ The remittitur case did not specify the basis for the damage award.

While there are too few cases to allow us to compare lost profits to reasonable royalties in a statistically significant way, it is notable that in the rare instances in which courts intervened in the calculation of damages it tended to be in lost profits cases, despite the fact that roughly $90 \%$ of the damage awards in the database were solely reasonable royalty awards. The rarity with which judges intervened at all in patent damages suggests that as a practical matter, whatever number the jury chooses is unlikely to be dislodged. ${ }^{35}$

Something similar occurs with expert testimony on damages. Despite the existence of the Daubert framework that permits judges to serve as gatekeepers in evaluating expert testimony, ${ }^{36}$ actual exclusions of testimony on patent damages are rare. Our review of Federal Circuit cases since 1993 found only 10 rulings in 9 cases on a Daubert motion in the context of patent damages. ${ }^{37}$ Of those 10 decisions, 4 involved only lost profits. ${ }^{38}$ Of the 6 decisions involving

If we added another $20 \%$ to the 25 decided cases, that would result in 23 total affirmances out of 30, rather than 18 out of 25.

28 See LexMachina, About, http://www.lexmachina.org/about.

29 Research on file with authors.

30 See infra App. tbl.2.

31 Id.

32 Id.

33 Id. Strictly speaking, courts do not grant remittitur of patent damages, but order a new trial unless the patentee will accept the remitted number.

${ }^{34}$ Id.

35 This does not mean JMOL in damage cases serves no purpose. It may pave the way for appellate argument.

36 Daubert v. Merrell Dow Pharmaceuticals, Inc., 509 U.S. 579, 597 (1993).

37 See infra App. tbl.3.

38 A fourth case involved both lost profits and reasonable royalties. Crystal Semiconductor Corp. v. TriTech Microelectronics Int’l, Inc., 246 F.3d 1336, 1342 (Fed. Cir. 2001). 
reasonable royalties, 5 allowed the testimony. ${ }^{39}$ In only 2 cases did the district court exclude testimony about reasonable royalties —one involving a patentee witness and one involving the accused infringer witness. And the case involving the patentee witness was reversed on appeal. ${ }^{40}$ It is also notable that of the 9 Federal Circuit decisions on Daubert damages issues, the Federal Circuit affirmed in 7, and the 2 cases that it did reverse both involved district court exclusions of damages testimony under Daubert. ${ }^{41}$

When we expand our search to include district courts, the numbers appear somewhat more favorable to Daubert challenges. There are 54 district court opinions since 2000 deciding Daubert motions in a patent damages case. ${ }^{42}$ Of those 54, 13 involved only lost profits, and 2 did not specify the basis for the damage award; we exclude those cases from our analysis. ${ }^{43}$ Of the 39 cases remaining, only 6 excluded the patentee's expert testimony on reasonable royalty, with another 3 excluding the patentee expert's testimony in part. ${ }^{44}$ The track record is somewhat better here than in the Federal Circuit. ${ }^{45}$ Still, while Daubert is sometimes used by district courts in patent damages cases, its effectiveness appears to be limited.

\section{STRUCTURING THE REASONABLE ROYALTY INQUIRY}

\section{A. Organizing and Simplifying the Georgia-Pacific Factors}

We think there is a better alternative. A review of the fifteen GeorgiaPacific factors, plus other considerations that courts and commentators have discussed, reveals that the relevant questions in calculating a reasonable royalty fall into four basic categories: (1) whether the patentee in fact produces a product in the market; (2) the contribution made by the patented technology compared to the next best alternative; (3) the number and importance of other inputs necessary to make that technology work; and (4) evidence of how the market has actually valued the patent, to the extent it differs from the outcome of (1), (2), and (3). We discuss each in turn.

\section{Nature of the Patentee}

A number of the Georgia-Pacific factors contemplate the classic historical pattern of suits by manufacturing companies that competed with the infringers. As one of us has noted elsewhere, patentees that compete with infringers

39 See infra App. tbl.3.

40 The Federal Circuit reversed the district court's JMOL on damages, but did not reach the question of whether the witness could testify on remand. Dow Chem. v. Mee Indus., Inc., 341 F.3d 1370, 1372-73 (Fed. Cir. 2003).

41 See infra App. tbl.3.

42 See infra App. tbl.4.

43 Id.

44 Id.

45 Notably, however, one of the district court decisions excluding testimony on Daubert grounds was authored by Federal Circuit Judge Randy Rader, sitting by designation. Cornell Univ. v. Hewlett-Packard Co., No. 01-CV-1974, 2008 WL 2222189 (N.D.N.Y. May 27, 2008). 
should be entitled to lost profits damages whenever possible. ${ }^{46}$ Reasonable royalties do not fit particularly well in those situations because a manufacturing patent owner normally will not license a competitor if it can produce the goods itself, so there should be no price on which a willing buyer and a willing seller can agree.

Georgia-Pacific factors three, four, five, and six seem designed to distinguish manufacturing from non-manufacturing entities. They provide:

3. The nature and scope of the license, as exclusive or non-exclusive; or as restricted or non-restricted in terms of territory or with respect to whom the manufactured product may be sold.

4. The licensor's established policy and marketing program to maintain his patent monopoly by not licensing others to use the invention or by granting licenses under special conditions designed to preserve that monopoly.

5. The commercial relationship between the licensor and licensee, such as, whether they are competitors in the same territory in the same line of business; or whether they are inventor and promotor.

6. The effect of selling the patented specialty in promoting sales of other products of the licensee; the existing value of the invention to the licensor as a generator of sales of his non-patented items; and the extent of such derivative or convoyed sales. ${ }^{47}$

At the very least, these factors expressly contemplate a patent owner that produces goods in the market, either directly or through an exclusive licensee. ${ }^{48}$ They have the purpose and should have the effect of generating higher royalties for patentees in that situation than for non-practicing entities. We think it makes more sense to expressly distinguish manufacturing from nonmanufacturing entities, either by entitling the former to lost profits or by separating the analysis of these factors, applying them only where the patentee competes with the infringer. ${ }^{49}$

46 See Mark A. Lemley, Distinguishing Lost Profits From Reasonable Royalties, 51 WM. \& MARY L. REV. 655, 656 (2009).

47 Georgia-Pac. Corp. v. U.S. Plywood Corp., 318 F. Supp. 1116, 1120 (S.D.N.Y. 1970).

48 A related case involves patentees that have already granted an exclusive license. In such a case, the exclusive licensee (and hence the patentee) is injured, but that injury should normally be compensable by lost profits. The patentee/exclusive licensee team should also be entitled to injunctive relief, though the Federal Circuit has affirmed the denial of that relief in Voda v. Cordis Corp., on the rather formalist theory that the exclusive licensee was not itself a party to the suit, so its injury should not count. 536 F.3d 1311, 1329 (Fed. Cir. 2008).

49 Some have derided this as "discrimination" against non-practicing entities. See Golden, supra note 2, at 2160; John M. Golden, Principles for Patent Remedies, 88 TEx. L. REV. 505, 556-57 (2010). Not so. The patent statute requires damages "adequate to compensate for infringement.” 35 U.S.C. $§ 284$ (2006). If the loss to one party is $\$ 1000$, and the loss to another party is $\$ 5000$, it would be foolish to say that both must be paid the same amount to avoid "discriminating" between them. To the contrary, it is the rule that requires unlike parties to be treated alike that is truly discriminatory. 


\section{The Incremental Contribution of the Patented Technology}

Not surprisingly, a reasonable royalty designed to mimic the results of a hypothetical license negotiation between patentee and infringer should be strongly influenced by the value that the patented technology actually contributes. The more the patented technology is worth, the more a willing buyer would be willing to pay, and the more a willing seller could reasonably demand.

Some of the Georgia-Pacific factors directly reflect this intuition. Specifically, factors eight, nine, ten, and eleven consider the value of the patented technology:

8. The established profitability of the product made under the patent; its commercial success; and its current popularity.

9. The utility and advantages of the patent property over the old modes or devices, if any, that had been used for working out similar results.

10. The nature of the patented invention; the character of the commercial embodiment of it as owned and produced by the licensor; and the benefits to those who have used the invention.

11. The extent to which the infringer has made use of the invention; and any evidence probative of the value of that use. ${ }^{50}$

Other factors reflect a related insight- the incremental contribution of the patent license to the buyer is a function not just of the value of the patented technology, but of the legal rights the license confers. Thus, factor three considers " $[t]$ he nature and scope of the license, as exclusive or non-exclusive; or as restricted or non-restricted in terms of territory or with respect to whom the manufactured product may be sold." 51 An exclusive license is generally more valuable to the buyer than a non-exclusive one. In practice, however, this factor matters little once the first step has been resolved for the simple reason that reasonable royalty cases are almost definitionally about non-exclusive, rather than exclusive, rights. Similarly, factor seven considers "[t]he duration of the patent and the term of the license." ${ }^{, 52}$ But that question is not particularly meaningful, since a patent damage award does not have a particular term—it covers the period of infringement up to the date of judgment. ${ }^{53}$

Together, these factors ask a court to determine how valuable the patented technology is to the accused infringer and to the marketplace as a whole. That inquiry will be relatively straightforward where the patent covers the product as a whole, but is more complicated when-as often happens in complex industries - the patented invention is merely one of many contributors to the success of a product. When that happens, factors eight through eleven are designed to parse the value of the patented technology from the value of other

50 Georgia-Pac. Corp., 318 F. Supp. at 1120.

51 Id.

52 Id.

53 It is not necessarily clear whether an accused infringer would be willing to pay a higher royalty for a license of longer duration (because it is more valuable to get rights for a longer period of time) or a license of shorter duration (because the total financial outlay would not be as great, since the royalty payments will end sooner). 
parts of the invention. If the patent covers a piece of a larger product, courts will have to scrutinize the evidence more carefully to determine what the patented piece contributes to the whole. Evidence of price changes after the feature is introduced, how products with and without the feature perform in competition with each other, available or likely design alternatives, and customer surveys about what buyers consider important may all help in this inquiry. Evidence of the actual market for the patented technology may also be used here subject to the caveats we discuss below.

Importantly, a patented invention may contribute not only by making a product more desirable, but also by making it cheaper to produce. Where the asserted value is on the production side, different sorts of evidence will become important, including evidence of production costs before and after the invention, design alternatives and their costs, and the like. But the goal is the same - to determine the value of the patented technology — which in turn will heavily influence how much patentees can reasonably demand for it and how much willing buyers will pay for it.

Determining the incremental contribution of the patented technology requires a baseline for comparison. Buyers are not buying the technology in a vacuum; they are almost always choosing among alternatives. Thus, the relevant question is how much more valuable the patented technology is than the next available noninfringing alternative. That framework is well-established in the lost profits case law, ${ }^{54}$ but it makes even more sense in evaluating reasonable royalties. If a patented technology saves me 3\% in costs over my existing alternative, I won't pay more than $3 \%$ for the right to use it.

The analysis becomes more complicated if the choice is between two technologies patented by different companies, rather than between the patent and a public domain alternative. If two equally attractive alternatives are both patented, the right measure of damages is neither $\$ 0$ nor the full value that one technology would offer if the other didn't exist. Because the technologies compete, a willing buyer in a real-world transaction could negotiate a better price from one patent owner by threatening to buy from the other instead, just as competition disciplines price in any other sector of the economy. The exact amount of the likely payment depends on how duopoly markets actually equilibrate, something on which economists differ. ${ }^{55}$

In any event, despite these complications, the basic inquiry in each case is the same: what does the patented technology give the buyer that she couldn't get elsewhere, and how valuable is that thing?

\section{Other Inputs to the Patented Invention}

The reader might reasonably ask whether the inquiry should stop at this point. We have determined the incremental value of the patentee's contribution. What else is left to do?

54 See, e.g., Grain Processing Corp. v. Am. Maize-Prods. Co., 185 F.3d 1341, 1349 (Fed. Cir. 1999).

55 For a description of the various models, see Guy Sagi, The Oligopolistic Pricing Problem: A Suggested Price Freeze Remedy, 2008 Colum. Bus. L. Rev. 269, 272-86 (2008). 
In fact, however, the real world is not quite so straightforward. There are additional complications that need to be considered. While we have determined the incremental value of the patented technology, it does not follow that the entirety of that value should be transferred to the patentee. The defendant is being sued because it, not the patentee, actually built the infringing product. As a result, the defendant likely contributed in part to the success of the patented technology as it is being sold, by paying to manufacture and market it or by bundling it with the defendant's own technological contributions. The GeorgiaPacific factors consider this as well, in factor thirteen: "The portion of the realizable profit that should be credited to the invention as distinguished from non-patented elements, the manufacturing process, business risks, or significant features or improvements added by the infringer." ${ }^{56}$ Most of this can be accounted for, in the typical case, by being careful to base the royalty rate on a share of the profits attributable to the patented invention, rather than on a larger measure such as actual sales of the invention. ${ }^{57}$ What a willing buyer would pay for the patented technology surely would not exceed the profit it can make from that technology. Indeed, in the real world it would almost certainly be less: How the surplus is divided in actual license negotiations depends on the position of the parties in bargaining. ${ }^{58}$

One important "input" is not accounted for by profits, however: the possibility of other patents covering the same technology. This "patent thicket"

56 Georgia-Pac. Corp., 318 F. Supp. at 1120.

57 The Federal Circuit has suggested that a reasonable royalty can exceed the profits made by the accused infringer. See Monsanto Co. v. Ralph, 382 F.3d 1374, 1384 (Fed. Cir. 2004) ("[A]lthough an infringer's anticipated profit from use of the patented invention is '[a]mong the factors to be considered in determining' a reasonable royalty, ... the law does not require that an infringer be permitted to make a profit.” (citing Georgia-Pac. Corp., 318 F. Supp at 1120)); State Indus., Inc. v. Mor-Flo Indus., Inc., 883 F.2d 1573, 1580 (Fed. Cir. 1989) ("There is no rule that a royalty be no higher than the infringer's net profit margin.”). The statement in Monsanto seems to us to be wrong; perhaps the law does not require that an infringer be permitted to make a profit, but there would be little reason for an infringer to agree to a royalty rate that did not permit him to do so. Likewise, it seems to us that State Industries can be right only if the market is such that the accused infringer would be able to increase its prices and still be competitive. In a highly concentrated market (where, for example, the only two competitors are the patent holder and the accused infringer) that might be so. But in the normal case, an accused infringer is not going to take a license at a rate that would cause it to lose money on each sale of the patented technology. To the contrary, the analysis needs to take into account not just the profit margin on the particular transaction, but other uses to which that money could be put, should the royalty payments make the use of the patented technology less profitable than other alternative investments.

58 See Lemley \& Shapiro, supra note 2, at 2000. Lemley and Shapiro are agnostic on the question of how this surplus should be divided. By contrast, those who attack the Lemley-Shapiro framework generally do so by assuming that the patentee is entitled to capture the full social surplus associated with the invention. Golden, supra note 2, at 2116 (arguing that Lemley and Shapiro haven't justified a benchmark rate that would divide the surplus); Elhauge, supra note 2, at 543 (arguing that the entire surplus from the bargain belongs to the patentee). But that assumption is odd; in no other area of the economy do we strive to ensure that a producer is paid the full social surplus for its goods. See Brett M. Frischmann \& Mark A. Lemley, Spillovers, 107 Colum. L. Rev. 257, 258 (2007). For criticism of the Elhauge approach, see Thomas F. Cotter, Patent Holdup, Patent Remedies, and Antitrust Responses, 34 J. CORP. L. 1151, 1152-53 (2009). 
is particularly pronounced in the information technology industries, ${ }^{59}$ but it shows up in other areas as well, including biotechnology. ${ }^{60}$ Even basic technical standards sometimes have hundreds or even thousands of "essential" patents covering them. ${ }^{61}$ The intensity of the patent thicket should be taken into account in setting a reasonable royalty. A willing buyer might be willing to pay up to $3 \%$ for a technology that reduces its costs by $3 \%$, but it surely isn't willing to pay 3\% to each of ten different patent owners claiming rights in the technology. As a result, courts should consider the number of other successful, pending, and potential patent claims on a technology in deciding how to allocate royalties for that technology. ${ }^{62}$

Factor three in our test, in short, ensures that patentees are not overcompensated —and infringers not inappropriately punished ${ }^{63}$-by awarding to one patentee profits that are in fact attributable to the efforts of another-either the infringer itself or a competing patentee.

\section{The Relevance of Actual Negotiations}

Georgia-Pacific factors one, two, and twelve relate to what might seem the most obvious piece of evidence to be used in calculating a reasonable royaltyactual royalties charged for this or other comparable inventions in the industry:

1. The royalties received by the patentee for the licensing of the patent in suit, proving or tending to prove an established royalty.

2. The rates paid by the licensee for the use of other patents comparable to the patent in suit.

$\cdots$

59 BurK \& Lemley, supra note 3, at 89-90; Carl Shapiro, Navigating the Patent Thicket: Cross Licenses, Patent Pools, and Standard Setting, in 1 InNOvation POLICY \& THE ECONOMY 119 (Adam B. Jaffe et al. eds., 2001).

${ }^{60}$ Cf. Michael A. Heller \& Rebecca S. Eisenberg, Can Patents Deter Innovation? The Anticommons in Biomedical Research, 280 SCIENCE 698, 698-99 (1998) (discussing the "anticommons" problem). Heller and Eisenberg are discussing a related but distinct problem-the number of patents on different technologies that must be aggregated to produce a useful product.

61 Examples can be found in Lemley \& Shapiro, supra note 2, at 2016.

62 In a forthcoming work, one of us offers some thoughts on the process by which courts might collect and use this information.

63 Some might argue that punishment of adjudged infringers is appropriate. In fact, however, virtually all patent infringement is inadvertent, not the result of intentional wrongdoing. See Christopher A. Cotropia \& Mark A. Lemley, Copying in Patent Law, 87 N.C. L. REV. 1421, 1441-42 (2009) (finding that at least $90 \%$ of patent suits involve inadvertent infringement). When infringement is intentional, the willfulness doctrine already provides for trebling of actual damages. In re Seagate Tech., LLC, 497 F.3d 1360, 1368 n.3 (Fed. Cir. 2007) (en banc). In any event, the purpose of patent damages is to compensate patentees for their losses, not to punish defendants or require them to disgorge their gains. A patentee's expected royalty in a hypothetical negotiation is unlikely to differ based on the mental state of the potential licensee. 
12. The portion of the profit or of the selling price that may be customary in the particular business or in comparable businesses to allow for the use of the invention or analogous inventions. ${ }^{64}$

After all, if the point of the reasonable royalty negotiation is to mimic what a willing buyer and willing seller would have agreed to, what better evidence than what other, presumably willing, buyers and sellers did in fact agree to?

In fact, however, we think evidence of this sort must be approached with a good deal of caution. In part this is because patents are by definition unique assets, making the price paid for a license to a different patent a less than perfect indicator of the value of the patent in suit. More importantly, license payments are payments to avoid infringement suits, and so the amount a licensee is willing to pay in a reasonable royalty case is a function of the damages she would expect to pay if she didn't take a license. Making the damages in turn depend on what the licensee is willing to pay introduces a problematic circularity into the process. ${ }^{65}$

The most significant problem with actual royalty data, however, is that the reasonable royalty inquiry is not in fact merely what a willing buyer would pay a willing seller. Rather, the operative question is what a willing buyer would have paid a willing seller if both parties knew at the time that the patent was valid and infringed. That is a big "if." Nearly half of all litigated patents are held invalid, ${ }^{66}$ and many of the rest are not infringed. Patentees win only just under a quarter of the cases they bring. ${ }^{67}$ Companies negotiating a license know this, and licenses incorporate that uncertainty in the royalty rate. As a result, a damage award that just reflected what parties to actual licenses agreed upon would systematically undercompensate patent owners. It might even encourage potential licensees to take their chances in court, figuring that if they lost they would just have to pay a normal license fee, though anyone who did in fact make that decision is probably a willful infringer subject to enhanced damages. The problem is compounded by the fact that, even in business negotiations, the threat of litigation as an alternative to a negotiated license-with the attendant legal fees, transaction costs, and uncertainty-often looms large. ${ }^{68}$

Actual royalties, then, cannot simply be used as a basis on which to calculate damages. They must be enhanced to counteract the discount that negotiating parties place on the likelihood that the patent is valid and

64 Georgia-Pac. Corp. v. U.S. Plywood Corp., 318 F. Supp. 1116, 1120 (S.D.N.Y. 1970)

65 This issue is explored further in Lemley \& Shapiro, supra note 2, at 2021.

66 John R. Allison \& Mark A. Lemley, Empirical Evidence on the Validity of Litigated Patents, 26 AIPLA Q.J. 185, 205 (1998) (forty-six percent of litigated patents held invalid).

${ }^{67}$ Paul M. Janicke \& LiLan Ren, Who Wins Patent Infringement Cases?, 34 AIPLA Q.J. 1, 8 (2006) (overall patentee win rate 24.4\%).

68 This concern is particularly acute where the sales of an accused product are relatively small, or where the target company does not have significant cash on hand, and thus avoided litigation costs in the millions are sufficient to justify a "high" royalty rate. 
infringed. ${ }^{69}$ As a result, we think these factors are best viewed, not as a starting point for the damages calculation, but as a check on the results of the prior three steps. The evidence supporting the prior three steps will often be indirect; the market may in fact provide clear and direct evidence that contradicts the results of the prior calculus. But that market evidence cannot simply be the royalties actually paid; it must take into account the fact that the patent has now been held valid and infringed.

\section{What About Factors Fourteen and Fifteen?}

The structured analysis we just described incorporates factors one though thirteen. What about factors fourteen and fifteen?

14. The opinion testimony of qualified experts.

15. The amount that a licensor (such as the patentee) and a licensee (such as the infringer) would have agreed upon (at the time the infringement began) if both had been reasonably and voluntarily trying to reach an agreement; that is, the amount which a prudent licensee - who desired, as a business proposition, to obtain a license to manufacture and sell a particular article embodying the patented invention - would have been willing to pay as a royalty and yet be able to make a reasonable profit and which amount would have been acceptable by a prudent patentee who was willing to grant a license. $^{70}$

In our view, these are not really factors to be weighed at all. Expert testimony is a source of evidence, one that is likely to predominate in all of the other factors. But it is not itself of importance what experts say, but rather what evidence they offer that fits into the other factors we have discussed. Factor fifteen is similarly a "meta-factor," but for a different reason: It represents the ultimate question all of the other factors are trying to establish.

\section{B. The Advantages of a Structured Approach}

Reconceiving the Georgia-Pacific factors in this way doesn't materially change the substantive content of the Georgia-Pacific analysis. But a structured approach turns what is now a multi-factor morass into which courts cannot easily venture to a straightforward series of questions on which the parties can provide evidence, and to which juries can give answers. By doing so, it facilitates both judicial control of damages evidence during trial and judicial review of jury verdicts. An expert will no longer be able simply to opine about how the factors should add up. Experts can provide evidence about lost-profitsstyle kickers, but only if they are relevant. They can provide evidence about what the patent contributes compared to available non-infringing alternatives. They can provide evidence about how that contribution must be apportioned

69 For a discussion of the differences between settlement licenses and damage awards, albeit one that would allow reliance on such licensees, see Michael J. Chapman, Using Settlement Licenses in Reasonable Royalty Determinations, 49 IDEA 313, 345-56 (2009).

${ }^{70}$ Georgia-Pac. Corp. v. U.S. Plywood Corp., 318 F. Supp. 1116, 1120 (S.D.N.Y. 1970). 
among different claimants. And in specialized circumstances, they can introduce evidence of other market transactions that may bear on what the market would consider a reasonable royalty rate. But it should be clear exactly what experts are in fact offering to testify about, and courts will have the power to exclude testimony that doesn't fit within that framework. ${ }^{71}$

The structured approach also makes possible special verdict forms that facilitate real judicial review of jury fact-finding. ${ }^{72}$ As noted in Part I, it is virtually impossible to evaluate a simple damages number for sufficiency of the evidence, given the wide range of potentially relevant factors that can be combined in any possible way. But by structuring the inquiry, courts can direct the jury to separate practicing from non-practicing entity cases, require them to assess the value of the patentee's contribution, and then to apportion that value. Doing so should encourage juries to assess damages properly. And if the resulting damages award is not properly derived from those subsidiary factual findings, the transparency of the structured approach will make that fact evident, and it will facilitate judicial review.

As a result, we view this approach as consistent with—indeed, a necessary complement to- the procedural approach to damages reform adopted by the Senate in Senate Bill 515. The bill gives courts the authority to review damages methodologies and rules with a critical eye; a structured approach to the calculation of those damages makes that review workable.

\section{CONCLUSION}

Reasonable royalty damage awards are a mess. Damage awards, rationales, and percentages are widely disparate, reflecting an uncertain legal environment and very little oversight of jury fact-finding. The solution to this problem lies, not in changing the substance of damage law, but in changing the process, structuring the inquiry so that the steps that should be followed in calculating a reasonable royalty are transparent to all.

${ }^{71}$ Cf. Patent Reform Act of 2009, S. 515, 111th Cong. § 284(a)(2) (2009), which may facilitate the use of Daubert to exclude suspect evidence on damages.

72 See Gooding \& Rooklidge, supra note 17, at 493-95 (advocating greater use of special verdict forms). 


\section{APPENDIX}

Table 1: Federal Circuit Cases Reviewing Reasonable Royalty Awards

\begin{tabular}{|c|c|c|}
\hline CASE NAME & CitATION & OUTCOME \\
\hline $\begin{array}{l}\text { Carborundum Co. v. Molten Metal } \\
\text { Equip. Innovations, Inc. }\end{array}$ & 72 F.3d 872 (Fed. Cir. 1995). & $\begin{array}{l}\text { Outcome not included in results; } \\
\text { lost profits case. }\end{array}$ \\
\hline Deere \& Co. v. Int’l Harvester Co. & 710 F.2d 1551 (Fed. Cir. 1983). & Affirmed \\
\hline Dow Chem. Co. v. Mee Indus., Inc. & 341 F.3d 1370 (Fed. Cir. 2003). & $\begin{array}{l}\text { Outcome not included in results; } \\
\text { not an opinion on the merits. }\end{array}$ \\
\hline Dow Chem. Co. v. United States & 226 F.3d 1334 (Fed. Cir. 2001). & Reversed and Remanded \\
\hline $\begin{array}{c}\text { Fromson v. W. Litho Plate \& Supply } \\
\text { Co. }\end{array}$ & 853 F.2d 1568 (Fed. Cir. 1988). & Reversed and remanded \\
\hline Gargoyles, Inc. v. United States & 113 F.3d 1572 (Fed. Cir. 1997). & Affirmed \\
\hline Glenayre Elecs., Inc. v. Jackson & 443 F.3d 851 (Fed. Cir. 2006) & $\begin{array}{l}\text { Outcome not included in results; } \\
\text { not an opinion on the merits. }\end{array}$ \\
\hline $\begin{array}{l}\text { Hanson v. Alpine Valley Ski Area, } \\
\text { Inc. }\end{array}$ & 718 F.2d 1075 (Fed. Cir. 1983). & Affirmed \\
\hline Haworth, Inc. v. Steelcase, Inc. & 12 F.3d 1090 (Fed. Cir. 1993). & $\begin{array}{l}\text { Outcome not included in results; } \\
\text { not an opinion on the merits. }\end{array}$ \\
\hline $\begin{array}{l}\text { Heeling Sports Ltd. v. U.S. Furong } \\
\text { Int'l Inc. }\end{array}$ & $\begin{array}{l}319 \text { F. App’x } 905 \text { (Fed. Cir. } \\
\text { 2009). }\end{array}$ & Reversed and Remanded \\
\hline $\begin{array}{l}\text { Hughes Tool Co. v. Dresser Indus., } \\
\text { Inc. }\end{array}$ & 816 F.2d 1549 (Fed. Cir. 1987). & Reversed and Remanded \\
\hline $\begin{array}{c}\text { Imonex Servs., Inc. v. W.H. } \\
\text { Munzprufer Dietmar Trenner } \\
\text { GMBH }\end{array}$ & 408 F.3d 1374 (Fed. Cir. 2005). & Affirmed \\
\hline $\begin{array}{l}\text { Interactive Pictures Corp. v. Infinite } \\
\text { Pictures, Inc. }\end{array}$ & 274 F.3d 1371 (Fed. Cir. 2001). & Affirmed \\
\hline King Instruments Corp. v. Perego & 65 F.3d 941 (Fed. Cir. 1995). & $\begin{array}{l}\text { Outcome not included in results; } \\
\text { lost profits case. }\end{array}$ \\
\hline Maxwell v. J. Baker, Inc. & 86 F.3d 1098 (Fed. Cir. 1996). & Affirmed \\
\hline Micro Chem., Inc. v. Lextron, Inc. & 317 F.3d 1387 (Fed. Cir. 2003). & Affirmed \\
\hline Minks v. Polaris Indus., Inc. & 546 F.3d 1364 (Fed. Cir. 2008). & $\begin{array}{l}\text { JMOL reversed; new trial } \\
\text { ordered }\end{array}$ \\
\hline Monsanto Co. v. Ralph & 382 F.3d 1374 (Fed. Cir. 2004). & Affirmed \\
\hline $\begin{array}{l}\text { Parental Guide of Texas, Inc. v. } \\
\text { Thomson, Inc. }\end{array}$ & 446 F.3d 1265 (Fed. Cir. 2006). & Affirmed \\
\hline $\begin{array}{c}\text { Paymaster Techs., Inc. v. United } \\
\text { States }\end{array}$ & $\begin{array}{l}180 \text { F. App’x } 942 \text { (Fed. Cir. } \\
\text { 2006). }\end{array}$ & Affirmed \\
\hline $\begin{array}{l}\text { Railroad Dynamics, Inc. v. A. Stucki } \\
\text { Co. }\end{array}$ & 727 F.2d 1506 (Fed. Cir. 1984). & Affirmed \\
\hline $\begin{array}{l}\text { Revolution Eyewear v. Aspex } \\
\text { Eyewear }\end{array}$ & 563 F.3d 1358 (Fed. Cir. 2009). & Affirmed \\
\hline Rite-Hite Corp. v. Kelley Co., Inc. & 56 F.3d 1538 (Fed. Cir. 1995). & Affirmed \\
\hline $\begin{array}{l}\text { SmithKline Diagnostics, Inc. v. } \\
\text { Helena Labs. Corp. }\end{array}$ & 926 F.2d 1161 (Fed. Cir. 1991). & Affirmed \\
\hline $\begin{array}{l}\text { State Contracting \& Eng'g Corp. v. } \\
\text { Condotte Am., Inc. }\end{array}$ & 346 F.3d 1057 (Fed. Cir. 2003). & Affirmed \\
\hline Stickle v. Heublein, Inc. & 716 F.2d 1550 (Fed. Cir. 1983). & Reversed and Remanded \\
\hline $\begin{array}{l}\text { Sun Studs, Inc. v. ATA Equip. } \\
\text { Leasing, Inc. }\end{array}$ & 872 F.2d 978 (Fed. Cir. 1989). & Affirmed \\
\hline
\end{tabular}




\begin{tabular}{|c|c|c|}
\hline CASE NAmE & CiTATION & Outcome \\
\hline $\begin{array}{c}\text { T.J. Smith \& Nephew Ltd. v. Parke, } \\
\text { Davis \& Co. }\end{array}$ & 9 F.3d 979 (Fed. Cir. 1993). & Affirmed \\
\hline $\begin{array}{c}\text { Trans-World Mfg. Corp. v. Al } \\
\text { Nyman \& Sons, Inc. }\end{array}$ & 750 F.2d 1552 (Fed. Cir. 1984). & $\begin{array}{c}\text { Outcome not included in results; } \\
\text { not an opinion on the merits; lost } \\
\text { profits case. }\end{array}$ \\
\hline TWM Mfg. Co., Inc. v. Dura Corp. & 789 F.2d 895 (Fed. Cir. 1986). & Affirmed \\
\hline $\begin{array}{c}\text { Unisplay, S.A. v. Am. Elec. Sign } \\
\text { Co., Inc. }\end{array}$ & 69 F.3d 512 (Fed. Cir. 1995). & Reversed and Remanded \\
\hline
\end{tabular}


Table 2: Granting of Judgment as a Matter of Law for Defendant After Jury Trial

\begin{tabular}{|c|c|c|c|c|c|}
\hline CASE & Citation & $\begin{array}{c}\text { REVERSED } \\
\text { JURY VERDICT } \\
\text { AND/OR } \\
\text { GRANTING } \\
\text { JMOL TO } \\
\text { PATANTEE }\end{array}$ & $\begin{array}{c}\text { GRANTED } \\
\text { JMOL ON THE } \\
\text { SUBSTANTIVE } \\
\text { MERITS TO } \\
\text { ACCUSED- } \\
\text { INFRINGER }\end{array}$ & $\begin{array}{l}\text { GRANTED } \\
\text { JMOL ON } \\
\text { DAMAGES TO } \\
\text { INFRINGER }\end{array}$ & $\begin{array}{c}\text { VACATING } \\
\text { DAMAGE } \\
\text { AWARD OR } \\
\text { GRANTING } \\
\text { REMITTITUR }\end{array}$ \\
\hline $\begin{array}{l}\text { ACCO Brands, Inc. } \\
\text { v. ABA Locks } \\
\text { Mfrs. Co. }\end{array}$ & $\begin{array}{l}501 \text { F.3d } 1307 \\
\text { (Fed. Cir. 2007) }\end{array}$ & & $\mathrm{X}$ & & \\
\hline $\begin{array}{c}\text { Aguayo v. } \\
\text { Universal } \\
\text { Instruments Corp. }\end{array}$ & $\begin{array}{l}356 \text { F. Supp. 2d } \\
699 \text { (S.D. Tex. } \\
\text { 2005). }\end{array}$ & & $\mathrm{X}$ & & \\
\hline $\begin{array}{l}\text { Avid Identification } \\
\text { Sys., Inc. v. } \\
\text { Phillips Elecs. N. } \\
\text { Am. Corp. }\end{array}$ & $\begin{array}{l}2008 \text { WL } 819962 \\
\text { (E.D. Tex. March } \\
\text { 25, 2008). }\end{array}$ & & $\mathrm{X}$ & & \\
\hline $\begin{array}{l}\text { Briggs \& Stratton } \\
\text { Corp. v. Kohler Co. }\end{array}$ & $\begin{array}{c}2006 \text { WL } \\
\text { 1601739 (W.D. } \\
\text { Wis. May 30, } \\
\text { 2006). }\end{array}$ & $\mathrm{X}$ & & & \\
\hline $\begin{array}{l}\text { Coca-Cola Co. v. } \\
\text { Tarabula }\end{array}$ & $\begin{array}{l}\text { 1:02-CV-02531- } \\
\text { CAP (N.D. Ga. } \\
\text { Jan. 24, 2006). }\end{array}$ & & & $\mathrm{X}$ & $\begin{array}{c}\text { Vacated } \\
\text { Damage Award }\end{array}$ \\
\hline $\begin{array}{l}\text { Devon Distrib. } \\
\text { Corp. v. Miner }\end{array}$ & $\begin{array}{l}525 \text { F. Supp. 2d } \\
1089 \text { (S.D. Iowa } \\
\text { 2007). }\end{array}$ & $\mathrm{X}$ & & & \\
\hline $\begin{array}{l}\text { Eaton Corp. v. } \\
\text { Parker-Hannifin } \\
\text { Corp. }\end{array}$ & $\begin{array}{l}292 \text { F. Supp. 2d } \\
555 \text { (D. Del. } \\
\text { 2003). }\end{array}$ & & $\mathrm{X}$ & & \\
\hline $\begin{array}{l}\text { Frazier v. Layne } \\
\text { Christiansen Co. }\end{array}$ & $\begin{array}{l}239 \text { F. App'x } 604 \\
\text { (Fed. Cir. 2007). }\end{array}$ & & $\mathrm{X}$ & & \\
\hline $\begin{array}{l}\text { Fresenius Med. } \\
\text { Care Holdings, Inc. } \\
\text { v. Baxter Int'l, Inc. }\end{array}$ & $\begin{array}{l}2007 \text { WL } 518804 \\
\text { (N.D. Cal. Feb. } \\
\text { 14, 2007). }\end{array}$ & $\mathrm{X}$ & & & \\
\hline $\begin{array}{l}\text { Geo M. Martin Co. } \\
\text { v. Alliance Mach. } \\
\text { Sys. Int'l, LLC }\end{array}$ & $\begin{array}{l}634 \text { F. Supp. 2d } \\
1024 \text { (N.D. Cal. } \\
\text { 2008). }\end{array}$ & & $\mathrm{X}$ & & \\
\hline $\begin{array}{l}\text { Glenayre Elecs. v. } \\
\text { Jackson }\end{array}$ & $\begin{array}{c}2003 \text { WL } \\
\text { 21639116 (N.D. } \\
\text { Ill. July 9, 2003). }\end{array}$ & & & $\mathrm{X}$ & $\begin{array}{c}\text { Granted } \\
\text { Remittitur }\end{array}$ \\
\hline $\begin{array}{l}\text { Golden Hour Data } \\
\text { Sys., Inc. v. } \\
\text { emsCharts, Inc. }\end{array}$ & $\begin{array}{l}2009 \text { WL } 943273 \\
\text { (E.D. Tex. April } \\
\text { 3, 2009). }\end{array}$ & & $\mathrm{X}$ & & \\
\hline $\begin{array}{l}\text { Iowa State Univ. } \\
\text { Research Found. v. } \\
\text { Wiley Organics, } \\
\text { Inc. }\end{array}$ & $\begin{array}{l}125 \text { F. App'x } 291 \\
\text { (Fed. Cir. 2005). }\end{array}$ & $\mathrm{X}$ & & & \\
\hline Jones v. S.A. Walls & $\begin{array}{l}\text { 07-CV-107-GKF- } \\
\text { PJC (N.D. Okla. } \\
\text { July 2, 2009). }\end{array}$ & & $\mathrm{X}$ & & \\
\hline $\begin{array}{l}\text { Kim v. ConAgra } \\
\text { Foods, Inc. }\end{array}$ & $\begin{array}{c}465 \text { F.3d } 1312 \\
\text { (Fed. Cir. 2006). }\end{array}$ & & $\mathrm{X}$ & & \\
\hline $\begin{array}{l}\text { Lucent Techs., Inc. } \\
\text { v. Gateway, Inc. }\end{array}$ & $\begin{array}{c}580 \text { F.3d } 1301 \\
\text { (Fed. Cir. 2009). }\end{array}$ & & & $\mathrm{X}$ & $\begin{array}{c}\text { Vacated } \\
\text { Damage Award }\end{array}$ \\
\hline
\end{tabular}




\begin{tabular}{|c|c|c|c|c|c|}
\hline CASE & CitATION & $\begin{array}{c}\text { REVERSED } \\
\text { JURY VERDICT } \\
\text { AND/OR } \\
\text { GRANTING } \\
\text { JMOL TO } \\
\text { PATANTEE }\end{array}$ & $\begin{array}{l}\text { GRANTED } \\
\text { JMOL ON THE } \\
\text { SUBSTANTIVE } \\
\text { MERITS TO } \\
\text { ACCUSED- } \\
\text { INFRINGER }\end{array}$ & $\begin{array}{l}\text { GRANTED } \\
\text { JMOL ON } \\
\text { DAMAGES TO } \\
\text { INFRINGER }\end{array}$ & $\begin{array}{c}\text { VACATING } \\
\text { DAMAGE } \\
\text { AWARD OR } \\
\text { GRANTING } \\
\text { REMITTITUR }\end{array}$ \\
\hline $\begin{array}{l}\text { Mannatech, Inc. v. } \\
\text { Glycoproducts Int'l, } \\
\text { Inc. }\end{array}$ & $\begin{array}{c}2008 \text { WL } \\
2704425 \text { (N.D. } \\
\text { Tex. 2008). }\end{array}$ & $\mathrm{X}$ & & & \\
\hline $\begin{array}{l}\text { Martek Biosciences } \\
\text { Corp. v. Nutrinova } \\
\text { Inc. }\end{array}$ & $\begin{array}{l}520 \text { F. Supp. 2d } \\
537 \text { (D. Del. } \\
\text { 2007). }\end{array}$ & & X (Partially) & & \\
\hline $\begin{array}{l}\text { Mercury Enters. v. } \\
\text { Ventlab Corp. }\end{array}$ & $\begin{array}{c}\text { 8:01-cv-02092- } \\
\text { RAL }\end{array}$ & & $\mathrm{X}$ & & \\
\hline $\begin{array}{l}\text { NexMed Holdings, } \\
\text { Inc. v. Block Inv., } \\
\text { Inc. }\end{array}$ & $\begin{array}{c}2008 \text { WL } \\
1901699 \text { (D. Utah } \\
\text { April 8, 2008). }\end{array}$ & $\mathrm{X}$ & & & \\
\hline $\begin{array}{l}\text { Novartis Pharma } \\
\text { Corp. v. Abbott } \\
\text { Labs. }\end{array}$ & $\begin{array}{l}294 \text { F. Supp. 2d } \\
557 \text { (D. Del. } \\
\text { 2003). }\end{array}$ & & $\mathrm{X}$ & & \\
\hline $\begin{array}{l}\text { NPF, Ltd. v. Smart } \\
\text { Parts, Inc. }\end{array}$ & $\begin{array}{l}187 \text { F. App'x } 973 \\
\text { (Fed. Cir. 2006). }\end{array}$ & & $\mathrm{X}$ & & \\
\hline $\begin{array}{c}\text { Putnam v. Henkel } \\
\text { Consumer } \\
\text { Adhesives, Inc. }\end{array}$ & $\begin{array}{l}\text { 1:05-CV-02011- } \\
\text { BBM (N.D. Ga. } \\
\text { Jan. 30, 2008). }\end{array}$ & & $\mathrm{X}$ & & \\
\hline $\begin{array}{l}\text { Syngenta Seeds Inc. } \\
\text { v. Monsanto Co. }\end{array}$ & $\begin{array}{l}431 \text { F. Supp. 2d } \\
482 \text { (D. Del. } \\
\text { 2006). }\end{array}$ & & $\mathrm{X}$ & & \\
\hline $\begin{array}{l}\text { TGIP, Inc. v. } \\
\text { AT\&T Corp. }\end{array}$ & $\begin{array}{l}527 \text { F. Supp. 2d } \\
561 \text { (E.D. Tex. } \\
\text { 2007). }\end{array}$ & & $\mathrm{X}$ & & \\
\hline $\begin{array}{l}\text { Ti Group Auto. v. } \\
\text { Vdo N. Am. }\end{array}$ & $\begin{array}{c}2002 \text { WL } \\
31051602 \text { (D. } \\
\text { Del. 2002). }\end{array}$ & & $\mathrm{X}$ & & \\
\hline $\begin{array}{l}\text { Wyers v. Master } \\
\text { Lock Co. }\end{array}$ & $\begin{array}{c}\text { 06-cv-00619-LTB } \\
\text { (D. Colo. May 8, } \\
\text { 2009). }\end{array}$ & $\mathrm{X}$ & & & \\
\hline
\end{tabular}


Table 3: Daubert Challenge Cases

\begin{tabular}{|c|c|c|c|c|c|}
\hline CASE & $\begin{array}{l}\text { DISTRICT COURT } \\
\text { DECISION }\end{array}$ & $\begin{array}{l}\text { APPELLATE } \\
\text { DECISION }\end{array}$ & $\begin{array}{l}\text { ADMITTED/ } \\
\text { EXCLUDED BY } \\
\text { COURT }\end{array}$ & $\begin{array}{c}\text { REASONABLE } \\
\text { ROYALTY/ } \\
\text { LOST } \\
\text { PROFITS }\end{array}$ & $\begin{array}{c}\text { PATENTEE/ } \\
\text { ACCUSED } \\
\text { INFRINGER } \\
\text { WITNESS }\end{array}$ \\
\hline $\begin{array}{c}\text { Atmel Corp. v. } \\
\text { Silicon Storage } \\
\text { Tech.* }\end{array}$ & $\begin{array}{l}202 \text { F. Supp. 2d } \\
1096 \text { (N.D. Cal. } \\
\text { 2002). }\end{array}$ & $\begin{array}{l}76 \text { F. App’x } 298 \\
\text { (Fed. Cir. 2003). }\end{array}$ & A & RR/LP & $\mathrm{P}$ \\
\hline $\begin{array}{c}\text { Crystal } \\
\text { Semiconductor v. } \\
\text { TriTech } \\
\text { Microelectronics** }\end{array}$ & $\begin{array}{l}\text { No. A 97-CA- } \\
\text { 026-SS, (W.D. } \\
\text { Tex. July 23, } \\
\text { 1999). }\end{array}$ & $\begin{array}{l}246 \text { F.3d } 1336 \\
\text { (Fed. Cir. 2001). }\end{array}$ & A & LP & P \\
\hline $\begin{array}{l}\text { Dow Chem. v. Mee } \\
\text { Indus.** }\end{array}$ & $\begin{array}{l}\text { 264 F. Supp. 2d } \\
1018 \text { (M.D. Fla. } \\
\text { 2002). }\end{array}$ & $\begin{array}{c}341 \text { F.3d } 1370 \\
\text { (Fed. Cir. 2003). }\end{array}$ & E & RR & $\mathrm{P}$ \\
\hline $\begin{array}{l}\text { Go Med. Indus. Pty. } \\
\text { Ltd. v. Inmed. } \\
\text { Corp.* }\end{array}$ & $\begin{array}{c}300 \text { F. Supp. 2d } \\
1297 \text { (N.D. Ga. } \\
\text { 2003). }\end{array}$ & $\begin{array}{c}471 \text { F.3d } 1273 \\
\text { (Fed. Cir. 2006). }\end{array}$ & E & LP & I \\
\hline $\begin{array}{l}\text { i4i Ltd. P'ship v. } \\
\text { Microsoft* }\end{array}$ & $\begin{array}{l}\text { No. 6:07CV113, } \\
\text { 2009 WL } \\
2449024 \text { (E.D. } \\
\text { Tex. Aug. 11, } \\
\text { 1999). }\end{array}$ & $\begin{array}{l}\text { No. 2009-1504, } \\
\text { 2010 WL 801705 } \\
\text { (Fed. Cir. Mar. } \\
\text { 10, 2010). }\end{array}$ & A & RR & $P$ \\
\hline $\begin{array}{l}\text { Imonex Servs. v. } \\
\text { W.H. Munzprufer* }\end{array}$ & $\begin{array}{l}\text { No. 2-01-CV- } \\
\text { 174-TJW (E.D. } \\
\text { Tex. Jan. 10, } \\
\text { 2003). }\end{array}$ & $\begin{array}{c}408 \text { F.3d } 1374 \\
\text { (Fed. Cir. 2005). }\end{array}$ & E & LP & P \\
\hline $\begin{array}{l}\text { Imonex Servs. v. } \\
\text { W.H. Munzprufer* }\end{array}$ & $\begin{array}{c}\text { No. 2-01-CV- } \\
\text { 174-TJW (E.D. } \\
\text { Tex. Jan. 10, } \\
\text { 2003). }\end{array}$ & $\begin{array}{c}408 \text { F.3d } 1374 \\
\text { (Fed. Cir. 2005). }\end{array}$ & A & RR & I \\
\hline $\begin{array}{l}\text { Maxwell v. Angel- } \\
\text { Etts of California* }\end{array}$ & $\begin{array}{c}\text { No. } \\
\text { CV9910516DT } \\
\text { (AJWX), 2001 } \\
\text { Wl 34133507 } \\
\text { (C.D. Cal. 2001). }\end{array}$ & $\begin{array}{l}53 \text { F. App’x } 561 \\
\text { (Fed. Cir. 2002). }\end{array}$ & A & RR & P \\
\hline $\begin{array}{l}\text { Monsanto v. } \\
\text { McFarling* }\end{array}$ & $\begin{array}{c}\text { No. 4:00CV84 } \\
\text { CDP, } 2005 \text { WL } \\
\text { 1490051 (E.D. } \\
\text { Mo. June 23, } \\
\text { 2005). }\end{array}$ & $\begin{array}{c}488 \text { F.3d } 973 \\
\text { (Fed. Cir. 2007). }\end{array}$ & A & RR & P \\
\hline $\begin{array}{l}\text { Utah Med. Prods. v. } \\
\text { Graphic Controls } \\
\text { Corp.* }\end{array}$ & $\begin{array}{c}\text { No. } \\
\text { 2:97CV427C, } \\
\text { 2000 WL } \\
\text { 33710853 (D. } \\
\text { Utah Sept. 11, } \\
\text { 2000). }\end{array}$ & $\begin{array}{c}350 \text { F.3d } 1376 \\
\text { (Fed. Cir. 2003). }\end{array}$ & E & RR & I \\
\hline
\end{tabular}

* Affirmed by appellate court.

** Reversed by appellate court. 
Table 4: Daubert in District Court Decisions

\begin{tabular}{|c|c|c|c|c|}
\hline CASE & CitATION & $\begin{array}{l}\text { ADMITTED/ } \\
\text { EXCLUDED BY } \\
\text { COURT }\end{array}$ & $\begin{array}{l}\text { REASONABLE } \\
\text { ROYALTY/ } \\
\text { LOST } \\
\text { PROFITS }\end{array}$ & $\begin{array}{l}\text { PATENTEE/ } \\
\text { ACCUSED } \\
\text { INFRINGER } \\
\text { WITNESS }\end{array}$ \\
\hline $\begin{array}{l}\text { Arlington Indus., Inc. v. } \\
\text { Bridgeport Fittings, Inc. }\end{array}$ & $\begin{array}{l}\text { No. 3:01-CV-0485, } 2009 \\
\text { WL 2973472 (M.D. Pa. } \\
\text { Sept. 10, 2009). }\end{array}$ & A & LP & $\mathrm{P}$ \\
\hline $\begin{array}{l}\text { Aspex Eyewear, Inc. v. E'Lite } \\
\text { Optik, Inc. }\end{array}$ & $\begin{array}{l}\text { No. 398-2996, } 2002 \text { WL } \\
\text { 1751381 (N.D. Tex. Apr. } \\
\text { 04, 2002). }\end{array}$ & A & $\mathrm{LP} / \mathrm{RR}$ & $P$ \\
\hline $\begin{array}{l}\text { Avocent Huntsville Corp. v. } \\
\text { ClearCube Tech., Inc. * }\end{array}$ & $\begin{array}{l}\text { No. 03-S-2875, } 2006 \text { WL } \\
2109503 \text { (N.D. Ala. July } \\
\text { 28, 2006). }\end{array}$ & $\mathrm{E}$ & $\mathrm{RR}$ & I \\
\hline $\begin{array}{l}\text { Avocent Huntsville Corp. v. } \\
\text { ClearCube Tech., Inc. * }\end{array}$ & $\begin{array}{l}\text { No. 03-S-2875, } 2006 \text { WL } \\
2109503 \text { (N.D. Ala., July } \\
\text { 28, 2006). }\end{array}$ & A & $\mathrm{RR}$ & $\mathrm{P}$ \\
\hline Bowling v. Hasbro, Inc. & $\begin{array}{l}\text { No. 05-229S, } 2008 \text { WL } \\
717741 \text { (D.R.I. Mar. 17, } \\
\text { 2008). }\end{array}$ & $\mathrm{E}$ & RR & $\mathrm{P}$ \\
\hline $\begin{array}{l}\text { Cornell Univ. v. Hewlett- } \\
\text { Packard Co. }\end{array}$ & $\begin{array}{l}\text { No. 01-CV-1974, } 2008 \\
\text { WL } 2222189 \text { (N.D.N.Y. } \\
\text { May 27, 2008). }\end{array}$ & $\mathrm{E}$ & $\mathrm{RR}$ & $P$ \\
\hline $\begin{array}{l}\text { Cryovac Inc. v. Pechiney } \\
\text { Plastic Packaging, Inc. }\end{array}$ & $\begin{array}{l}430 \text { F. Supp. 2d } 346 \text { (D. } \\
\text { Del. 2006). }\end{array}$ & $\mathrm{A} / \mathrm{E}$ & LP & I \\
\hline Dow Chem. v. Mee Indus. & $\begin{array}{l}264 \text { F. Supp. 2d } 1018 \\
\text { (M.D. Fla. 2002). }\end{array}$ & $\mathrm{E}$ & $\mathrm{RR}$ & $\mathrm{P}$ \\
\hline $\begin{array}{l}\text { DSU Med. Corp. v. JMS Co., } \\
\text { Ltd. }\end{array}$ & $\begin{array}{l}296 \text { F. Supp. 2d } 1140 \\
\text { (N.D. Cal. 2003). }\end{array}$ & $\mathrm{A} / \mathrm{E}$ & LP & $\mathrm{P}$ \\
\hline $\begin{array}{l}\text { Engineered Prods. Co. v. } \\
\text { Donaldson Co., Inc. }\end{array}$ & $\begin{array}{l}313 \text { F. Supp. 2d } 951 \text { (N.D. } \\
\text { Iowa 2004). }\end{array}$ & A & LP & $\mathrm{P}$ \\
\hline $\begin{array}{l}\text { EZ Dock, Inc. v. Schafer Sys., } \\
\text { Inc. }\end{array}$ & $\begin{array}{c}\text { No. 98-2364, } 2003 \text { WL } \\
\text { 1610781 (D. Minn. Mar. } \\
\text { 8, 2003). }\end{array}$ & $\mathrm{A} / \mathrm{E}$ & $\mathrm{RR} / \mathrm{LP}$ & $\mathrm{P}$ \\
\hline $\begin{array}{c}\text { Floe Int'l, Inc. v. Newman's } \\
\text { Mfg. Inc. }\end{array}$ & $\begin{array}{l}\text { No. 04-5120, } 2006 \text { WL } \\
2590649 \text { (D. Minn. July 7, } \\
\text { 2006). }\end{array}$ & A & $\mathrm{RR}$ & $P$ \\
\hline $\begin{array}{l}\text { Fresenius Med. Care } \\
\text { Holdings, Inc. v. Baxter Int'l, } \\
\text { Inc. }\end{array}$ & $\begin{array}{c}\text { No. 03-1431, } 2006 \text { WL } \\
\text { 1390416 (N.D. Cal. May } \\
\text { 18, 2006). }\end{array}$ & A & $\mathrm{RR}$ & I \\
\hline $\begin{array}{c}\text { Haemonetics Corp. v. Baxter } \\
\text { Healthcare Corp. }\end{array}$ & $\begin{array}{l}593 \text { F. Supp. 2d } 303 \text { (D. } \\
\text { Mass. 2009). }\end{array}$ & A & LP & $\mathrm{P}$ \\
\hline $\begin{array}{c}\text { Henrob Ltd. v. Bollhoff } \\
\text { Systemtechnick GmbH \& Co. }\end{array}$ & $\begin{array}{l}\text { No. 05-CV-73214, } 2009 \\
\text { WL 3199855, (E.D. Mich. } \\
\text { Sept. 29, 2009). }\end{array}$ & A & $\mathrm{RR}$ & $\mathrm{P}$ \\
\hline i4i Ltd. P'ship v. Microsoft & $\begin{array}{l}\text { No. 6:07CV113, } 2009 \text { WL } \\
\text { 2449024 (E.D. Tex. Aug. } \\
\text { 11, 2009). }\end{array}$ & A & $\mathrm{RR}$ & $\mathrm{P}$ \\
\hline $\begin{array}{l}\text { IGT v. Alliance Gaming } \\
\text { Corp. * }\end{array}$ & $\begin{array}{l}\text { No. 2:04-CV-1676, } 2008 \\
\text { WL 7084605 (D. Nev. } \\
\text { Oct. 21, 2008). }\end{array}$ & A & LP & I \\
\hline $\begin{array}{l}\text { IGT v. Alliance Gaming } \\
\text { Corp. * }\end{array}$ & $\begin{array}{l}\text { No. 2:04-CV-1676, } 2008 \\
\text { WL 7084605 (D. Nev. } \\
\text { Oct. 21, 2008). }\end{array}$ & A & LP & $\mathrm{P}$ \\
\hline
\end{tabular}




\begin{tabular}{|c|c|c|c|c|}
\hline CASE & CITATION & $\begin{array}{l}\text { ADMITTED/ } \\
\text { EXCLUDED BY } \\
\text { COURT }\end{array}$ & $\begin{array}{l}\text { REASONABLE } \\
\text { ROYALTY/ } \\
\text { LOST } \\
\text { PROFITS }\end{array}$ & $\begin{array}{l}\text { PATENTEE/ } \\
\text { ACCUSED } \\
\text { INFRINGER } \\
\text { WITNESS }\end{array}$ \\
\hline $\begin{array}{l}\text { IGT v. Alliance Gaming } \\
\text { Corp. * }\end{array}$ & $\begin{array}{l}\text { No. 2:04-CV-1676, } 2008 \\
\text { WL 7084606 (D. Nev. } \\
\text { Oct. 21, 2008). }\end{array}$ & A & LP & $\mathrm{P}$ \\
\hline $\begin{array}{l}\text { IGT v. Alliance Gaming } \\
\text { Corp. * }\end{array}$ & $\begin{array}{l}\text { No. 2:04-CV-1676, } 2008 \\
\text { WL 7084606 (D. Nev. } \\
\text { Oct. 21, 2008). }\end{array}$ & $\mathrm{A} / \mathrm{E}$ & LP & $\mathrm{P}$ \\
\hline $\begin{array}{l}\text { Inline Connection Corp. v. } \\
\text { AOL Time Warner Inc. }\end{array}$ & $\begin{array}{l}470 \text { F. Supp. 2d } 424 \text { (D. } \\
\text { Del. 2007). }\end{array}$ & $\mathrm{A} / \mathrm{E}$ & $\mathrm{RR}$ & $\mathrm{P}$ \\
\hline $\begin{array}{l}\text { Insight Tech. Inc. v. SureFire, } \\
\text { LLC }\end{array}$ & $\begin{array}{l}\text { No. 04-CV-074, } 2005 \text { WL } \\
6001396 \text { (D.N.H. Aug. 2, } \\
\text { 2005). }\end{array}$ & $\mathrm{E}$ & $\mathrm{LP} / \mathrm{RR}$ & $\mathrm{P}$ \\
\hline $\begin{array}{l}\text { Johnson Elec. N. Am. Inc. v. } \\
\text { Mabuchi Motor Am. Corp. }\end{array}$ & $\begin{array}{l}103 \text { F. Supp. 2d } 268 \\
\text { (S.D.N.Y. 2000). }\end{array}$ & $\mathrm{E}$ & LP & $\mathrm{P}$ \\
\hline $\begin{array}{c}\text { Juicy Whip, Inc. v. Orange } \\
\text { Bang, Inc. }\end{array}$ & $\begin{array}{c}\text { No. 96-08148, } 2002 \text { WL } \\
\text { 32954976 (C.D. Cal. Dec. } \\
\text { 16, 2002). }\end{array}$ & $\mathrm{E}$ & LP & $\mathrm{P}$ \\
\hline $\begin{array}{l}\text { Keystone Retaining Wall } \\
\text { Sys., Inc. v. Rockwood } \\
\text { Retaining Wall, Inc. }\end{array}$ & $\begin{array}{c}\text { No. 00-496, } 2001 \text { WL } \\
\text { 36102284 (D. Minn. Oct. } \\
\text { 9, 2001). }\end{array}$ & A & $\mathrm{RR}$ & I \\
\hline $\begin{array}{l}\text { Koito Mfg. Co., Ltd. v. Turn- } \\
\text { Key-Tech, LLC }\end{array}$ & $\begin{array}{l}\text { No. 02-CV-0273, } 2003 \\
\text { WL } 25674799 \text { (S.D. Cal. } \\
\text { Apr. 10, 2003). }\end{array}$ & A & $\mathrm{RR}$ & $\mathrm{P}$ \\
\hline $\begin{array}{l}\text { LP Matthews LLC v. Bath \& } \\
\text { Body Works, Inc. }\end{array}$ & $\begin{array}{l}458 \text { F. Supp. 2d } 198 \text { (D. } \\
\text { Del. 2006). }\end{array}$ & A & RR & I \\
\hline $\begin{array}{l}\text { Maxwell v. Angel-Etts of } \\
\text { California }\end{array}$ & $\begin{array}{c}\text { No. CV9910516, } 2001 \\
\text { WL } 34133507 \text { (C.D. Cal. } \\
\text { July 9, 2001). }\end{array}$ & A & RR & $\mathrm{P}$ \\
\hline $\begin{array}{l}\text { Medtronic, Inc. v. Boston } \\
\text { Scientific Corp. * }\end{array}$ & $\begin{array}{l}\text { No. 99-1035, } 2002 \text { WL } \\
34447587 \text { (D. Minn., Aug. } \\
\text { 8, 2002). }\end{array}$ & $\mathrm{E}$ & $\mathrm{RR}$ & I \\
\hline $\begin{array}{l}\text { Medtronic, Inc. v. Boston } \\
\text { Scientific Corp. * }\end{array}$ & $\begin{array}{l}\text { No. 99-1035, } 2002 \text { WL } \\
\text { 34447587 (D. Minn. Aug. } \\
\text { 8, 2002). }\end{array}$ & $\mathrm{A} / \mathrm{E}$ & RR & $\mathrm{P}$ \\
\hline $\begin{array}{l}\text { MercExchange, L.L.C. v. } \\
\text { eBay, Inc. }\end{array}$ & $\begin{array}{l}275 \text { F. Supp. 2d } 695 \text { (E.D. } \\
\text { Va. 2003). }\end{array}$ & A & RR & $\mathrm{P}$ \\
\hline $\begin{array}{l}\text { Minemyer v. B-Roc } \\
\text { Representatives, Inc. }\end{array}$ & $\begin{array}{l}\text { No. } 07 \text { C } 1763,2009 \text { WL } \\
3757378 \text { (N.D. Ill. Oct. } \\
\text { 29, 2009). }\end{array}$ & A & LP/RR & $\mathrm{P}$ \\
\hline $\begin{array}{l}\text { Monolithic Power Sys., Inc. v. } \\
\text { O2 Micro Intern. Ltd. }\end{array}$ & $\begin{array}{l}\text { 476 F. Supp. 2d } 1143 \\
\text { (N.D. Cal. 2007). }\end{array}$ & $\mathrm{E}$ & $\mathrm{RR}$ & $\mathrm{P}$ \\
\hline Monsanto v. Tidball & $\begin{array}{l}\text { No. 4:07CV2079 CDP, } \\
\text { 2009 WL 2757047 (E.D. } \\
\text { Mo. Aug. 26, 2009). }\end{array}$ & E & $\mathrm{RR}$ & I \\
\hline $\begin{array}{l}\text { Oxford Gene Tech. Ltd. v. } \\
\text { Mergen Ltd. }\end{array}$ & $\begin{array}{l}345 \text { F. Supp. 2d } 431 \text { (D. } \\
\text { Del. 2004). }\end{array}$ & A & $\mathrm{RR}$ & I \\
\hline $\begin{array}{l}\text { Parker-Hannifin Corp. v. } \\
\text { Champion Labs., Inc. }\end{array}$ & $\begin{array}{l}\text { No. 1:06-CV-2616, } 2008 \\
\text { WL 1843922 (N.D. Ohio } \\
\text { April 22, 2008). }\end{array}$ & A & LP/RR & $\mathrm{P}$ \\
\hline $\begin{array}{l}\text { Parker-Hannifin Corp. v. } \\
\text { Champion Labs., Inc. }\end{array}$ & $\begin{array}{l}\text { No. 1:06-CV-2616, } 2008 \\
\text { WL 1843922 (N.D. Ohio } \\
\text { April 22, 2008). }\end{array}$ & A & $\mathrm{RR}$ & $\mathrm{P}$ \\
\hline $\begin{array}{c}\text { Pioneer Hi-Bred Intern. Inc. v. } \\
\text { Ottawa Plant Food, Inc. * }\end{array}$ & $\begin{array}{l}219 \text { F.R.D. } 135 \text { (N.D. } \\
\text { Iowa 2003). }\end{array}$ & A & $\mathrm{RR}$ & $\mathrm{I}$ \\
\hline
\end{tabular}




\begin{tabular}{|c|c|c|c|c|}
\hline CASE & CitATION & $\begin{array}{l}\text { ADMITTED/ } \\
\text { EXCLUDED BY } \\
\text { COURT }\end{array}$ & $\begin{array}{l}\text { REASONABLE } \\
\text { ROYALTY/ } \\
\text { LOST } \\
\text { PROFITS }\end{array}$ & $\begin{array}{c}\text { PATENTEE/ } \\
\text { ACCUSED } \\
\text { INFRINGER } \\
\text { WITNESS }\end{array}$ \\
\hline $\begin{array}{l}\text { Pioneer Hi-Bred Int'l Inc. v. } \\
\text { Ottawa Plant Food, Inc.* }\end{array}$ & $\begin{array}{l}219 \text { F.R.D. } 135 \text { (N.D. } \\
\text { Iowa 2003). }\end{array}$ & $\mathrm{E}$ & $\mathrm{RR}$ & I \\
\hline $\begin{array}{c}\text { Pioneer Hi-Bred Int’l Inc. v. } \\
\text { Ottawa Plant Food, Inc. * }\end{array}$ & $\begin{array}{l}219 \text { F.R.D. } 135 \text { (N.D. } \\
\text { Iowa 2003). }\end{array}$ & $\mathrm{A} / \mathrm{E}$ & $\mathrm{RR} / \mathrm{LP}$ & I \\
\hline $\begin{array}{l}\text { Pioneer Hi-Bred Int'l Inc. v. } \\
\text { Ottawa Plant Food, Inc. * }\end{array}$ & $\begin{array}{l}219 \text { F.R.D. } 135 \text { (N.D. } \\
\text { Iowa 2003). }\end{array}$ & A & $\mathrm{RR} / \mathrm{LP}$ & $\mathrm{P}$ \\
\hline $\begin{array}{c}\text { Putnam v. Henkel Consumer } \\
\text { Adhesives, Inc. }\end{array}$ & $\begin{array}{l}\text { No. 1:05-CV-2011, } 2007 \\
\text { WL 4794115 (N.D. Ga. } \\
\text { Oct. 29, 2007). }\end{array}$ & $\mathrm{A} / \mathrm{E}$ & $\mathrm{RR}$ & I \\
\hline $\begin{array}{l}\text { Putnam v. Henkel Consumer } \\
\text { Adhesives, Inc. }\end{array}$ & $\begin{array}{l}\text { No. 1:05-CV-2011, } 2007 \\
\text { WL 4794115 (N.D. Ga. } \\
\text { Oct. 29, 2007). }\end{array}$ & A & RR & $\mathrm{P}$ \\
\hline $\begin{array}{l}\text { Reedhycalog UK, Ltd. v. } \\
\text { Baker Hughes Oilfield } \\
\text { Operations Inc. }\end{array}$ & $\begin{array}{l}\text { No. 6:06-CV-222, } 2008 \\
\text { WL 5572567 (E.D. Tex. } \\
\text { May 20, 2008). }\end{array}$ & A & N/A & I \\
\hline $\begin{array}{c}\text { Rembrandt Data Techs., LP v. } \\
\text { AOL }\end{array}$ & $\begin{array}{l}\text { No. 1:08cv1009, } 2009 \\
\text { WL 2242624 (E.D. Va. } \\
\text { June 17, 2009). }\end{array}$ & A & RR & $\mathrm{P}$ \\
\hline $\begin{array}{l}\text { Seitz v. Envirotech Sys. } \\
\text { Worldwide Inc. }\end{array}$ & $\begin{array}{l}\text { No. H-02-4782, } 2008 \text { WL } \\
656513 \text { (S.D. Tex. Mar. 6, } \\
\text { 2008). }\end{array}$ & A & LP/RR & $\mathrm{P}$ \\
\hline $\begin{array}{c}\text { Sharp Corp. v. AU Optronics } \\
\text { Corp. }\end{array}$ & $\begin{array}{c}\text { No. 03-4244, } 2005 \text { WL } \\
1457747 \text { (N.D. Cal. June } \\
\text { 20, 2005). }\end{array}$ & A & N/A & $\mathrm{P}$ \\
\hline $\begin{array}{l}\text { Sigma Tool \& Mach. v. } \\
\text { Nagayama Elec. Indus. Co., } \\
\text { Ltd. }\end{array}$ & $\begin{array}{l}\text { No. 00-2936, } 2002 \text { WL } \\
\text { 34354482 (D.D.C. Dec. } \\
\text { 18, 2002). }\end{array}$ & A & LP & $\mathrm{P}$ \\
\hline $\begin{array}{l}\text { Spreadsheet Automation } \\
\text { Corp. v. Microsoft Corp. }\end{array}$ & $\begin{array}{l}587 \text { F. Supp. 2d } 794 \text { (E.D. } \\
\text { Tex. 2007). }\end{array}$ & $\mathrm{A} / \mathrm{E}$ & RR & $\mathrm{P}$ \\
\hline $\begin{array}{l}\text { St. Clair Intellectual Property } \\
\text { Consultants, Inc. v. Canon, } \\
\text { Inc. }\end{array}$ & $\begin{array}{l}\text { No. 03-241, } 2004 \text { WL } \\
\text { 2213562 (D. Del. Sept. } \\
\text { 28, 2004). }\end{array}$ & A & RR & $\mathrm{P}$ \\
\hline $\begin{array}{l}\text { Tech. Licensing Corp. v. } \\
\text { Gennum Corp. }\end{array}$ & $\begin{array}{l}\text { No. 3:01-CV-4204, } 2004 \\
\text { WL 1274391 (N.D. Cal. } \\
\text { Mar. 26, 2004). }\end{array}$ & $\mathrm{E}$ & $\mathrm{RR}$ & $\mathrm{P}$ \\
\hline $\begin{array}{l}\text { Transamerica Life Ins. Co. v. } \\
\text { Lincoln Nat'l Life Ins. Co. }\end{array}$ & $\begin{array}{c}\text { No. C 06-220, } 2008 \text { WL } \\
4787173 \text { (N.D. Iowa Oct. } \\
\text { 27, 2008). }\end{array}$ & A & LP & I \\
\hline $\begin{array}{l}\text { Uniloc USA, Inc. v. } \\
\text { Microsoft* }\end{array}$ & $\begin{array}{l}632 \text { F. Supp. 2d } 147 \\
\text { (D.R.I. 2009). }\end{array}$ & A & RR & I \\
\hline $\begin{array}{l}\text { Uniloc USA, Inc. v. } \\
\text { Microsoft* }\end{array}$ & $\begin{array}{l}632 \text { F. Supp. 2d } 147 \\
\text { (D.R.I. 2009). }\end{array}$ & A & $\mathrm{RR}$ & $\mathrm{P}$ \\
\hline \multicolumn{5}{|c|}{$\begin{array}{l}\text { * Cases listed multiple times denote multiple decisions under Daubert regarding expert } \\
\text { testimony on more than one topic. }\end{array}$} \\
\hline
\end{tabular}

